\title{
POTENSI CHIMERIC ANTIGEN RECEPTOR T CELL (CAR-T CELL) DENGAN TARGET PROSTATE- SPECIFIC MEMBRANE ANTIGEN (PSMA) TERMODIFIKASI CRISPR/CAS9 SEBAGAI TERAPI KANKER PROSTAT
}

\author{
Ali Habibi', Siti Zulaikha Risqiyani' ${ }^{1}$, Dwi Ari Santi Putri ${ }^{2}$ \\ ${ }^{1}$ Program Studi Pendidikan Dokter, Fakultas Kedokteran, Universitas Jember, Jember
}

Korespondensi:

Ali Habibi

Email author:

alisegaf21@gmail.com

Riwayat Artikel

Diterima: 12 Maret 2021 Selesai revisi: 5 Juni 2021

DOI :

10.53366/jimki.v9i1.321

\section{ABSTRAK}

Pendahuluan: Kanker prostat merupakan keganasan sel-sel prostat yang menjadi salah satu keganasan tersering pada pria dengan prevalensi 137,9 kasus baru per 100.000 pria tiap tahunnya. Salah satu pekerjaan yang memiliki risiko tinggi terhadap kejadian kanker prostat adalah petani karena diakibatkan pajanan pestisida dan zat berbahaya lainnya. Saat ini, Androgen Deprivation Therapy (ADT) masih menjadi terapi yang banyak digunakan. Namun, ADT dapat menurunkan libido, impotensi, hot flashes, dan peningkatan risiko patah tulang. Karena beberapa kelemahan dari terapi ADT, maka diperlukan inovasi terapi untuk kanker prostat.

Metode: Proses pencarian literatur yang relevan kami lakukan menggunakan metode PRISMA dengan kata kunci yang telah ditetapkan sebelumnya. Dari 94 jurnal yang telah ditelaah, 64 jurnal diantaranya dianggap sesuai dengan topik bahasan dan digunakan sebagai referensi.

Hasil dan Pembahasan: CAR-T Cell termodifikasi CRISPR/Cas9 terbukti efisien dan efektif meningkatkan fungsi $C A R-T$ Cell pada uji in vitro dan in vivo. Mekanisme imunosupresif yang diakibatkan oleh ikatan programmed cell death protein 1 (PD-1) dengan Programmed DeathLigand 1 (PD-L1) dapat dituntaskan dengan menggunakan metode CRISPR/Cas9-mediated anti PD-1 sehingga dapat mempertahankan aktivasi $C A R-T$ Cell. Hal ini dibuktikan dengan peningkatan degranulasi $C A R-T$ Cell dan clearance tumor pada uji in vivo.

Simpulan: Chimeric Antigen Receptor T Cell (CAR-T Cell) dengan target Prostate- Specific Membrane Antigen (PSMA) termodifikasi CRISPR/Cas9 berpotensi sebagai inovasi terapi yang efektif pada kanker prostat.

Kata Kunci: Chimeric Antigen Receptor $T$ Cell (CAR-T Cell), CRISPR/Cas9, Prostate Cancer, dan Prostate-Specific Membrane Antigen (PSMA) 


\title{
THE POTENTIAL OF CHIMERIC ANTIGEN RECEPTOR T CELL (CART-T CELL) TARGETTING PROSTATE-SPECIFIC MEMRANE ANTIGEN (PSMA) MODIFIED BY CRISPR/CAS9 AS PROSTATE CANCER THERAPY
}

\begin{abstract}
Introduction: Prostate cancer is a malignancy of prostate cells which is one of the most common malignancies in men with a prevalence of 137.9 new cases per 100,000 men each year. One of the jobs that have a high risk of prostate cancer is farmers because it is caused by exposure to pesticides and other hazardous substances. Currently, Androgen Deprivation Therapy (ADT) is still a widely used therapy. However, ADT can decrease libido, impotence, hot flashes, and an increased risk of fractures. Due to several disadvantages of ADT therapy, therapeutic innovations for prostate cancer are needed.

Method: We searched relevant literature using the PRISMA method with predefined keywords. Of the 94 journals that have been reviewed, 64 of them are considered according to the topic of discussion and are used as references.

Results and Discussion: CAR-T Cell modified CRISPR/Cas9 proved to be efficient and effective in increasing the function of CAR-T Cell on in vitro and in vivo tests. The immunosuppressive mechanism caused by $P D-1$ binding with $P D-L 1$ can be resolved using the CRISPR / Cas9-mediated anti PD-1 method so that it can maintain CAR-T Cell activation. This is evidenced by the increase in CAR-T cell degranulation and tumor clearance in the in vivo test.

Conclusion: Chimeric Antigen Receptor T Cell (CAR-T Cell) with a CRISPR/Cas9 modified Prostate-Specific Membrane Antigen (PSMA) target has the potential to be an effective therapeutic innovation for prostate cancer.
\end{abstract}

Keywords: Chimeric Antigen Receptor T Cell (CAR-T Cell), CRISPR/Cas9, Prostate Cancer, and Prostate-Specific Membrane Antigen (PSMA) 


\section{PENDAHULUAN}

Kanker prostat merupakan keganasan pada sel-sel prostat yang ditandai dengan peningkatan serum prostate specific antigen (PSA) dan keabnormalan colok dubur yang dipastikan dengan pemeriksaan biopsi prostat, transrectal ultrasonography (TRUS), prostate cancer gene 3 (PCA3), dan magnetic resonance imaging (MRI). ${ }^{[1,2,3]}$ Kanker prostat menyumbang $16 \%$ kematian di Indonesia. ${ }^{[4]}$ Kanker prostat adalah salah satu keganasan tersering pada pria dengan 137,9 kasus baru per 100.000 pria tiap tahunnya. ${ }^{[5,6,7]}$ Prevalensi kanker prostat di seluruh dunia pada tahun 2018 mencapai 1.276.106 kasus dengan kematian sebanyak 358.989.[6,8,9] Sampai tahun 2040, diperkirakan akan ada kasus baru sebanyak 2.293.818 kasus. ${ }^{[9,10]}$ Di Indonesia, jumlah penderita kanker prostat di tiga rumah sakit pusat pendidikan (Jakarta, Bandung, Surabaya) selama 8 tahun terakhir yaitu 1.102 pasien dengan bentuk terseringnya adalah adenokarsinoma. ${ }^{[11,12]}$

Beberapa mekanisme telah diajukan untuk menjelaskan perkembangan kanker akibat pestisida. Kebanyakan pestisida tidak bersifat mutagenik. Namun, pestisida mungkin mengandung endocrine disruptors yang bisa memblokir ataupun merangsang reseptor hormonal dan menyebabkan peningkatan testosteron. Namun, bukti dari studi epidemiologi, tidak dapat membuktikan dengan pasti bahwa paparan endocrine disruptors atau kadar androgen endogen yang bersirkulasi berhubungan dengan peningkatan risiko kanker prostat. Selain itu, penelitian pada hewan dan jaringan telah menunjukkan bahwa salah satu jenis pestisida yaitu karbamat, dapat menyebabkan kerusakan kromosom. Selain itu, pestisida juga dapat menyebabkan stres oksidatif yang dapat merusak sel. ${ }^{[13]}$

Pekerjaan petani memiliki risiko tinggi terhadap beberapa paparan berbahaya, seperti debu organik dan anorganik, pestisida, jamur, mikroba, virus, bensin, knalpot diesel, asap pengelasan, dan sinar ultraviolet ${ }^{[13]}$ yang dapat dikaitkan dengan beberapa jenis kanker, termasuk kanker prostat. ${ }^{[14]}$ Sejak tahun 1970-an, banyak penelitian melaporkan risiko kanker prostat yang signifikan pada petani dibandingkan dengan pekerjaan lain. ${ }^{[13]}$ Laporan terbaru dari Studi Kesehatan Pertanian (AHS), sebuah kelompok besar pengguna pestisida dan pasangan mereka, terkonfirmasi bahwa pestisida tertentu menjadi faktor utama risiko kanker yang diamati pada populasi pertanian. ${ }^{[15]}$

Penderita kanker prostat perlu dikelompokkan menjadi 3 kelompok, yaitu kelompok dengan risiko rendah, risiko menengah, dan risiko tinggi. Pengelompokan risiko dilakukan untuk menentukan jenis pengobatan kanker. Pengobatan kanker yang dimaksud terdiri dari observasi, operasi, radiasi, atau pengobatan paliatif dengan memberikan obat antihidrogen. ${ }^{[16]}$ Selama dekade terakhir ini, pengobatan kanker prostat telah berubah dengan terapi baru, pencitraan fungsional tingkat lanjut dan pembaruan dari terapi yang ada pada tahap awal..17] Terdapat beberapa faktor yang memengaruhi keberhasilan terapi, yaitu stadium, komorbiditas, dan grading. Faktor-faktor risiko ini perlu dikenali dan dikelola dengan baik dan benar untuk memilih opsi perawatan yang tepat dan meminimalkan efek samping dan perbaikan kualitas hidup. ${ }^{[18]}$

Terdapat banyak pengobatan baru untuk kanker prostat dengan imunoterapi, salah satunya yaitu sipuleucel-T (sip-T). Penggunaan imunoterapi berpotensi untuk 
meningkatkan kelangsungan hidup bagi pasien kanker prostat metastatik dengan melibatkan sistem kekebalan untuk menyerang sel-sel tumor. ${ }^{[19]}$ Akan tetapi, terapi ini menimbulkan efek samping, seperti flu dan demam sebagai efek samping yang paling umum. Efek samping yang lebih serius jarang terjadi. Kadang- kadang sistem kekebalan tubuh mulai menyerang bagian lain dari tubuh yang dapat menyebabkan masalah serius di paruparu, usus, hati, kelenjar pembuat hormon, ginjal, atau organ lain. [20]

$\begin{array}{rrr}\text { Dari } & \text { studi sebelumnya } \\ \text { menyatakan selain imunoterapi, }\end{array}$ Androgen Deprivation Therapy (ADT) masih menjadi strategi terapi yang banyak digunakan dalam praktik klinis yang bekerja dengan cara menghalangi efek androgen dan dapat memperlambat pertumbuhan kanker prostat. ${ }^{[17]}$ Androgen Deprivation Therapy sejauh ini menjadi standar terapi dan biasanya berlanjut seumur hidup untuk pasien dengan kanker prostat metastatik. Perkembangan Androgen Deprivation Therapy (ADT) untuk metastatic castration-resistant prostate cancer (mCRPC) diobati dengan penambahan manipulasi hormonal sekunder, termasuk antiandrogen seperti bicalutamide dan nilutamide, ketoconazole, atau kortikosteroid. ${ }^{[17]}$ Namun, ADT dapat menurunan libido, impotensi, hot flashes, osteopenia dengan peningkatan risiko patah tulang. ${ }^{[21]}$ Karena beberapa kelemahan dari terapi ADT, maka diperlukan inovasi terapi untuk kanker prostat, salah satunya dengan Chimeric Antigen Receptor $T$ cell (CAR-T) dengan target ProstateSpecific Membrane Antigen (PSMA) termodifikasi CRISPR/Cas9.

$$
\text { Terapi Chimeric Antigen }
$$

Receptor $T$ cell (CAR-T) telah mendapatkan perhatian besar karena keunggulan CAR-T dalam pengobatan tumor ganas pada sistem peredaran darah. Teknologi CAR-T memberikan cara baru untuk terapi tumor ganas, termasuk kanker prostat. ${ }^{[22]}$ CAR adalah protein transmembran yang disintesis, yang dapat mengenali antigen target yang diekspresikan dalam sel tumor melalui pemrograman ulang genetik. Teknologi transfer gen ini dapat memperkenalkan gen yang mengkode CARs ke dalam sel imun secara efisien.[23] CAR-T membutuhkan receptor transmembran spesifik untuk dikenali, salah satunya adalah PSMA (Prostate- specific membrane antigen).[22]

PSMA

(Prostate-specific membrane antigen) adalah glikoprotein transmembran tipe II yang diekspresikan pada membran sel epitel prostat. Prostate-Specific Membrane Antigen (PSMA) juga diekspresikan pada membran ovarium dan sel payudara dalam kadar yang rendah dan hampir tidak ada di usus, hati, membran sel ginjal, tetapi tinggi dalam jaringan prostat dan pembuluh darah tumor. Dengan demikian, PSMA memiliki spesifisitas jaringan prostat yang baik. Selain itu, PSMA dapat berfungsi sebagai reseptor untuk melakukan pensinyalan untuk meningkatkan migrasi sel dan mengatur stabilitas kromosom. Oleh karena itu, PSMA merupakan target antigen yang menjanjikan untuk terapi kanker prostat.[22]

Salah satu mekanisme dimana kanker dapat menghambat fungsi dari sel $T$ yaitu melalui mekanisme imunosupresif dengan mengekspresikan inhibitory ligand seperti PD-L1 pada sel kanker dan jaringan di sekitarnya (misalnya stroma atau tumor pembuluh darah) ekspresi protein PD -1 pada sel $T$ dan protein PD- L1 pada sel kanker berkorelasi dengan prognosis yang buruk pada beberapa kanker. Penelitian terbaru menunjukkan bahwa metode Clustered Regularly Interspaced Short Palindromic Repeats Associated with Cas9 protein (CRISPR/Cas9) dapat digunakan untuk menghilangkan 
mekanisme munosupresif yang dapat meningkatkan prospek terapi CAR-T melalui modifikasi gen. ${ }^{24]}$ CRISPR/Cas9 merupakan metode genome editing yang memiliki tingkat kespesifikan yang tinggi, tidak melibatkan integrasi antar-DNA, dan dapat menargetkan lebih dari satu genom target.[25] Oleh karena itu, untuk meningkatkan potensi dari CAR-T Cell pada terapi kanker prostat, kami mengajukan metode CRISPR/Cas9 untuk menghambat protein PD-1 pada CAR-T Cell, sehingga tidak bisa berikatan dengan protein PD-L1 pada sel tumor. Hal ini berefek pada CAR-T Cell menjadi tidak bisa dinonaktifkan. ${ }^{[24,26]}$

\section{METODE}

Penulisan karya ilmiah tinjauan pustaka ini menggunakan metode PRISMA (Preferred Reporting Items for Systemic Reviews and Meta-Analyses). PRISMA merupakan suatu studi pustaka yang didasarkan atas faktafakta serta pengambilan data secara random. Struktur yang digunakan dalam karya ilmiah ini mengaplikasikan: latar belakang, sasaran, sumber data, kriteria kelayakan jurnal, dan intervensi, study appraisal dan synthesis methods, hasil, batasan masalah, kesimpulan dan kata kunci, serta daftar pustaka. Penulis menggunakan search engine PubMed, ScienceDirect, GoogleSchoolar, Elsevier, Nature dengan kata kunci: "Prostate Cancer, Chimeric Antigen Receptor T Cell (CAR-T Cell), ProstateSpecific Membrane Antigen (PSMA), CRISPR/ Cas9, dan Agriculture". Jurnal ilmiah yang telah berhasil melewati kriteria inklusi dan eksklusi akan menjalani proses pemindaian kembali untuk mengetahui adanya publikasi tambahan mengenai kata kunci yang ditentukan. Jurnal ilmiah akan menjalani proses eksklusi jika tahun publikasi atau terbit jurnal telah melebihi 10 tahun, tidak relevan, dan bukan merupakan artikel full- text. Terdapat 94 artikel atau jurnal ilmiah yang sesuai dengan topik yang dibahas, tetapi hanya 65 jurnal yang memenuhi kriteria inklusi yang telah ditetapkan penulis.

\section{HASIL DAN PEMBAHASAN}

\subsection{Patogenesis Kanker Prostat}

Patogenesis yang berperan dalam kanker prostat diakibatkan oleh faktor androgen, hereditas, lingkungan, dan mutasi somatik.[27] Androgen, terutama testosteron dan dihidrotestosteron, merupakan hormon penting untuk pertumbuhan dan fungsi prostat, namun juga berperan dalam progresivitas dan metastasis kanker. ${ }^{[28,29]}$ Pajanan terhadap pestisida meningkatkan risiko kanker prostat melalui efek biologisnya dalam perubahan kadar dan fungsi hormon serta sebagai promotor tumor.[30] Salah satu respon dari androgen dalam sel kanker prostat adalah meningkatkan regulasi dari Transmembrane Serine Protease 2 (androgen-responsive TMPRSS2) yang diekspresikan pada sisi luminal epitel prostat. $^{[31]}$ Gen TMPRSS2 (Transmembrane Serine Protease 2) berfusi dengan ERG (ETSrelated gene) atau ETV1 (Variant Transcription Factor 1) yang merupakan faktor transkripsi ETS (E26 Transformation-Specific) family dan bersifat karsinogenik. ${ }^{32,33,34,35]}$

Riwayat keluarga dan latar belakang etnis sering diasosiasikan dengan peningkatan insiden kanker prostat sebagai predisposisi genetik dan herediter. ${ }^{[36]}$ Pada orang Amerika berkulit putih, terjadinya kanker prostat dikaitkan dengan suatu lokus pada kromosom 1q24-q25, sedangkan pada laki-laki keturunan Afrika, varian onkogen MYC pada kromosom 8q24 diduga sebagai penyebab peningkatan insidens kanker prostat. ${ }^{[1]}$ Mutasi sering mengakibatkan aktivasi PI3K/AKT signaling pathway yang bersifat onkogenik, di antaranya ialah mutasi yang rnenginaktifkan gen supresor tumor PTEN (Phosphatase and Tensin Homolog deleted on Chromosome 10), yang bertindak sebagai penghambat pada aktivitas PI3K. ${ }^{[1,37]}$ Perubahan struktural lainnya yang telah dikemukakan dalam kanker prostat yaitu fusi gen ESRP1- RAF1 (epithelial splicing regulatory protein-1-v-raf-1 murine leukemia viral oncogene homolog-1), ETS family, dan RAF kinase. ${ }^{[27,38]}$ Respon imun anti tumor, terutama sel $T$ sitotoksik atau sel $T$ $\mathrm{CD}^{+}$memediasi eliminasi sel kanker 
sehingga sel kanker tidak dapat berkembang dan bermetastasis. ${ }^{[39]}$ Pada kanker prostat tingkat lanjut, PD1 pathway dan ligannya yaitu PD-L1 muncul sebagai mekanisme toleransi imun yang menyebabkan sel tumor dapat menekan antitumor dengan cara menghambat fungsi efektor dan mengurangi efektivitas sel $\mathrm{T}$ (Lihat gambar 1). ${ }^{[40,41]}$ ositif PD-L1 sering dikaitkan dengan peningkatan risiko metastasis dan rekurensi. ${ }^{[42,43]}$

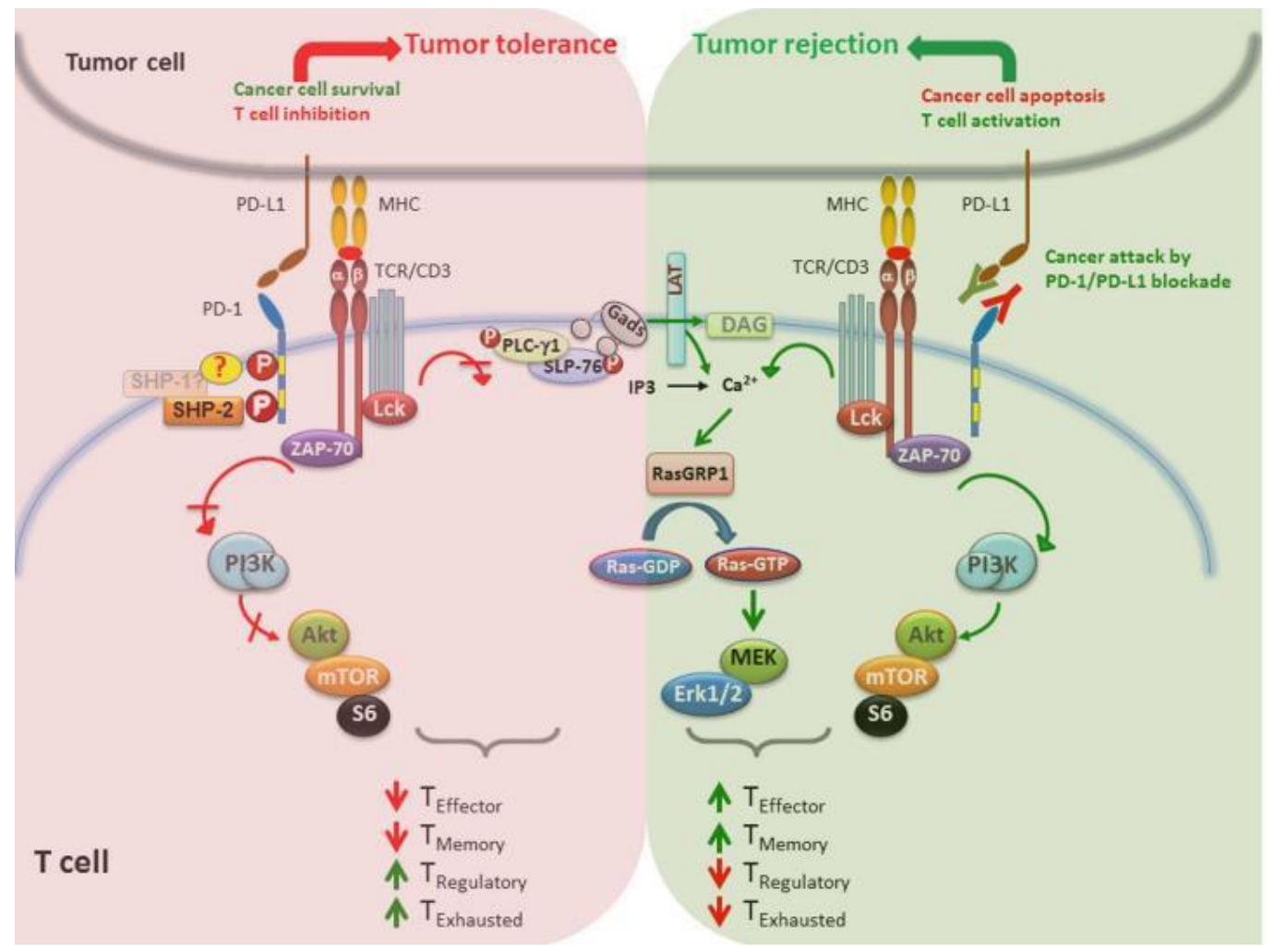

Gambar 1. Blokade PD-1 / PD-L1 meningkatkan regresi dan rejeksi tumor dengan mengaktifkan sel T. (Kiri) Ketika jalur PD-1/PD-L1 aktif, maka akan meningkatkan progresivitas sel kanker melalui sinyal antiapoptotik yang dimediasi PD-L1 dan menghambat jalur pensinyalan yang mengaktivasi sel $T$ (sel yang mengenali antigen tumor). Peristiwa ini menyebabkan rusaknya efektor T dan sel-sel memori serta diferensiasi sel TEX dan TReg, yang menyebabkan toleransi terhadap sel kanker. (Kanan) Berbeda dengan gangguan pensinyalan T-cell receptor $(T C R)$ yang disebabkan oleh PD-1, blokade PD-1 / PD-L1 meningkatkan kapasitas sel T dengan cara mengaktivasi jalur PI3K/Akt atau Ras/MAPK, menyebabkan diferensiasi sel T efektor dan memori serta supresi dari diferensiasi TEX dan Treg ${ }^{[44]}$ 


\subsection{Chimeric Antigen Receptor T Cell (CAR-T Cell)}

Terapi Chimeric antigen receptor (CAR-T) telah mendapatkan perhatian besar karena keunggulan sel-sel CAR-T dalam pengobatan tumor dan telah mendapat pengakuan besar atas hasil terapinya. ${ }^{[22]}$ Chimeric antigen receptor (CAR-T) merupakan metode transfer sel $\mathrm{T}$ yang direkayasa secara genetika dengan mengekspresikan Chimeric Antigen Receptor (CAR). ${ }^{[45]}$ Sel $T$ yang telah direkayasa secara ex vivo nantinya akan diarahkan terhadap antigen spesifik pada sel tumor. ${ }^{[46]}$ CAR sebagai reseptor sintetis menggunakan single-chain variable fragment (scFv) dalam penargetan antigen permukaan sel.[47] Fragmen scFv sendiri berperan sebagai tumor-associated antigens receptor (TAAs) atau reseptor antigen yang diekspresikan oleh sel-sel tumor. Selain fragmen scFv, terdapat beberapa komponen lain yang menjadi bagian reseptor CAR dalam sel $T$, yaitu domain transmembran dan immunoreceptor tyrosine-based activation motifs (ITAMs) yang merupakan bagian intraseluler.[48,49] Zona transmembran terdiri dari CD3, CD8, CD28, atau FceRI dan dapat memperbaiki scFv pada permukaan sel $\mathrm{T}$ dan mentransduksi sinyal ke dalam sel. Zona transduksi sinyal intraseluler terdiri dari CD8, CD28, atau CD137 dan CD3ろ, yang berisi immunoreceptor tyrosine-based activation motifs (ITAMs). [22]

\subsection{Peran Prostate-specific membrane antigen (PSMA) sebagai Target CAR-T Cell}

Dalam pengembangan terapi $C A R-T$ cell dibutuhkan pengenalan tentang reseptor antigen tumor atau tumor- associated antigens receptor (TAAs). Antigen yang terkait dengan kanker prostat dapat berupa protein yang ada pada sel prostat. Contohnya adalah prostate-specific antigen (PSA), prostatespecific membrane antigen (PSMA), dan prostate stem cell antigen (PSCA). ${ }^{[50]}$ Antigen terkait tumor yang paling umum digunakan untuk kanker prostat terapi CAR-T cell adalah PSMA.[22] Pada dua uji klinis fase 1, terapi $C A R-T$ cell dengan target PSMA dinilai aman. ${ }^{[1,52]}$

\begin{abstract}
Prostate-Specific Membrane Antigen (PSMA) memiliki berbagai nama lain, seperti glutamat karboksipeptidase II (GCP II), N-asetil-L-aspartil-L-glutamat peptidase I (NAALA Dase I), atau folat hidrolase, yaitu 100-kD glikoprotein transmembran tipe II golongan M28 peptidase. Protein PSMA memiliki glutamat carboxypeptidase aktif berperan untuk mengkatalisis neuropeptida N-asetil-L-aspartil-Lglutamat (NAAG) menjadi $\mathrm{N}$ asetillaspartat (NAA) dan glutamate. ${ }^{[53]}$

Beberapa molekul protein dan glikoprotein diekspresikan pada jaringan kanker prostat, yang berfungsi sebagai target untuk CAR-T Cell telah dijelaskan sebelumnya, seperti prostate-specific antigen (PSA), prostate-specific membrane antigen (PSMA), dan prostate stem cell antigen (PSCA). Reseptor CAR- T Cell dapat membaca frame protein, transient receptor potential-p8, dan enam transmembrane epithelial antigen pada sel prostat. ${ }^{[54]}$
\end{abstract}

Prostate-specific membrane antigen (PSMA) merupakan salah satu protein transmembran yang dapat dikenali oleh CAR-T Cell. Ekspresi PSMA rendah pada sel ovarium dan sel payudara, tetapi tinggi dalam jaringan prostat. ${ }^{[22,55]}$ Antigen ini diekspresikan pada permukaan sel pada jaringan prostat normal dan diekspresikan berlebih pada kanker prostat. Ekspresi PSMA akan semakin meningkat sebanding dengan tingkat keparahan tumor. Prostate-Specific Membrane Antigen (PSMA) diakui sebagai target pada kanker prostat sekitar 3 dekade lalu ketika antibodi pertama pada domain intraseluler dikembangkan. [56]

\subsection{Mekanisme terapi CAR-T Cell sebagai antitumor}

Sel-sel CAR-T dapat secara khusus mengenali antigen tumor dengan cara MHC-independen. Setelah CAR secara spesifik berikatan dengan TAA, sel $T$ akan diaktifkan melalui fosforilasi immune receptor tyrosinebased activation motifs (ITAM) diikuti oleh peningkatan sitokin (termasuk IL-2, IL-4, IFN- $\mathrm{y}, \mathrm{IL}-12$, dan TNF) sekresi, proliferasi sel T, dan sitotoksisitas. IL-12 dapat memperkuat fungsi sel imun bawaan seperti sel NK dan makrofag. Sel T dan CAR-T yang teraktivasi 
melakukan sitotoksisitas, terdapat 2 jalur, yaitu sekresi granula perforin dan granzyme, serta melalui jalur aktivasi reseptor sinyal yang menginduksi kematian sel melalui Fas/Fas-L (Lihat gambar 2). ${ }^{[47]}$

Sel T yang termodifikasi CD40L mampu memberikan efek dengan meningkatkan proliferasi dan sekresi sitokin Th1 proinflamasi, termasuk IL-2, IFN-y, IL-12, dan TNF. IL-12 berperan dalam peningkatan aktivasi sel $T$ sitotoksik. ${ }^{[57]}$ IFN-y yang disekresikan oleh sel CAR-T juga berkontribusi pada penghancuran sel tumor. ${ }^{[55]}$ Selain itu,
CD28 dijadikan sebagai co-stimulator dalam terapi CAR-T anti-PSMA generasi kedua yang diuji pada tikus, memiliki peran sangat penting untuk sekresi sitokin spesifik antigen dan proliferasi sel T. Sel- sel CAR-T generasi kedua menunjukkan efek merusak sel target yang lebih baik daripada generasi sebelumnya dan mewakili pendekatan target imun baru untuk mPCa. ${ }^{22,55]}$ Efeknya, volume tumor menurun secara signifikan (berkurang setelah 3 minggu) pada tikus yang diinokulasi dengan sel CAR-T anti-PSMA. ${ }^{[55,58]}$

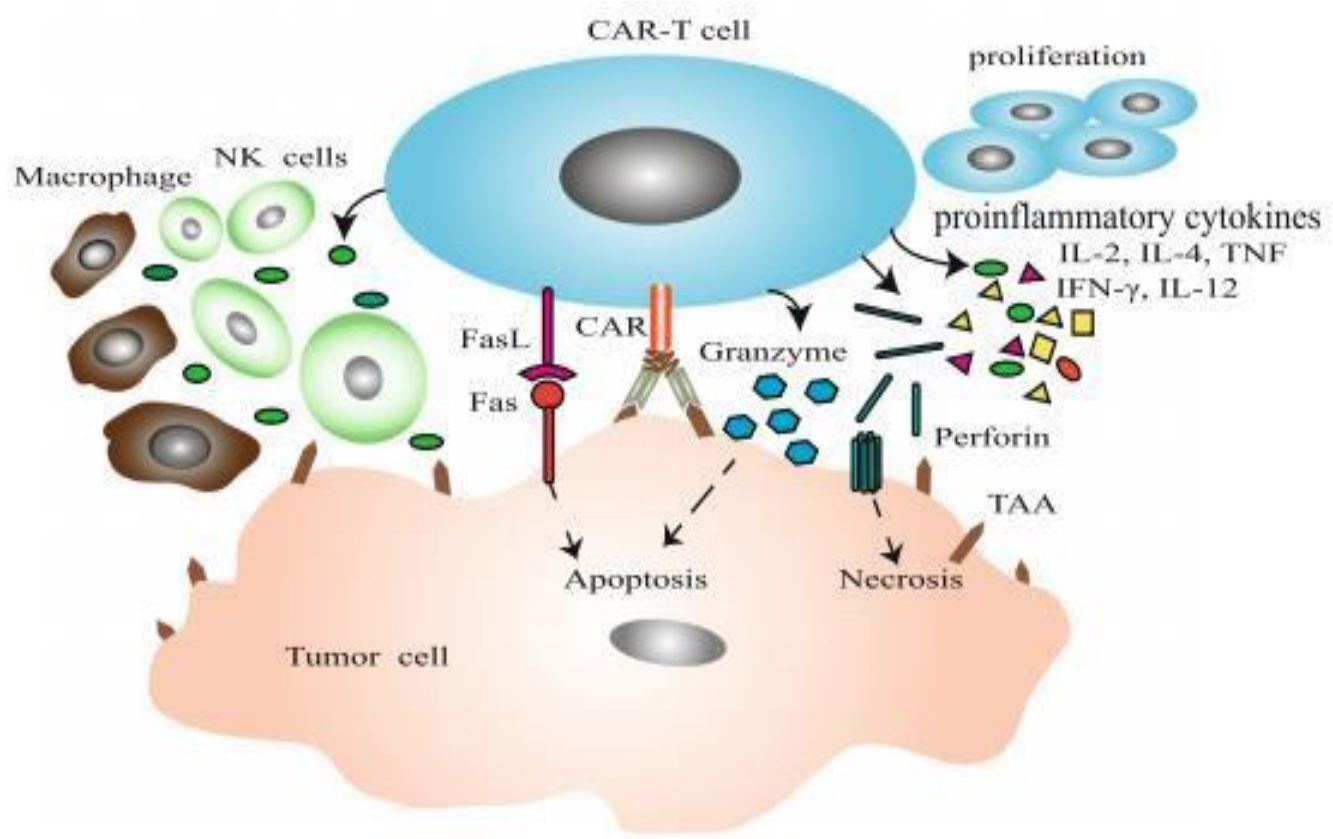

Gambar 2, Mekanisme CAR-T Cell sebagai anti-tumor ${ }^{[50]}$

\subsection{Prinsip dan Mekanisme Kerja CRISPR/Cas9}

Rekayasa genetik adalah teknologi yang sangat dibutuhkan dalam penelitian biologi dan aplikasi biomedis. Rekayasa genetik memungkinkan kita untuK mengubah sekuens genetik sesuka hati untuk mengatur informasi genetik fundamental dalam sel. Rekayasa ini telah diimplementasikan untuk studi fungsi gen atau genetika penyakit pada manusia, dan juga telah digunakan dalam terapi gen untuk memperbaiki perubahan genetik yang merugikan dan dapat memberi manfaat. [59]

Prinsip dasar untuk proses ini dapat dibagi menjadi dua langkah. Langkah pertama adalah pengenalan DNA cleavage yang ditargetkan, dalam bentuk double strand breaks (DSBs) atau single strand nicks (SSNs), melalui aktivitas nucleases atau nickases. Langkah kedua melibatkan proses DNA repair yang diaktifkan oleh cleavage yang ditargetkan, yang dilakukan secara normal oleh endogenous DNA damage repair machinery di dalam sel. [59]

Metode rekayasa genetik terbaru yang digunakan sebagai terapi gen adalah Clustered regularly interspaced short palindromic repeats (CRISPR) dan CRISPR-assosiated protein 9 (Cas9), yang merupakan sistem pertahanan pada bakteri S. pyogen dan telah terbukti bisa diterapkan pada sel manusia. [60] CRISPR mengacu pada sequences dalam genom bakteri. Sedangkan CRISPR-assosiated protein 9 (Cas9) adalah endonuklease yang memotong 
kedua untai DNA. Cas9 diarahkan menuju target pada DNA oleh bagian RNA. RNA ini dapat disintesis sebagai untai tunggal yang disebut synthetic single guide RNA (sgRNA); bagian RNA yang berikatan dengan DNA genomik yang tersusun dari 18-20 nukleotida. Untuk memotong, urutan DNA spesifik harus terletak pada ujung 3 ' dari sgRNA, ini disebut protospacer adjacent motif (PAM).[61]Proses perbaikan setelah pemotongan DNA dapat terjadi melalui dua jalur, yaitu non-homologous end joining (NHEJ), biasanya mengarah ke penyisipan/penghapusan bagian DNA, dan yang kedua adalah homology directed repair (HDR), di mana sepotong DNA homolog digunakan sebagai template perbaikan.[61] Kelebihan mekanisme perbaikan DNA endogen seluler NHEJ dibanding dengan mekanisme endogen seluler lainnya seperti Homology dorected repair (HDR) yang memperlukan template rantai DNA untuk melakukan perbaikan DNA adalah NHEJ bisa memperbaiki DNA melalui mutasi ketika sel sedang dalam fase membelah ataupun ketika sel dalam fase tidak membelah serta efektivitasnya yang lebih tinggi. Sedangkan HDR hanya mampu memperbaiki DNA yang terpotong ketika sel sedang dalam fase pembelahan G2 atau S. ${ }^{[62]}$

\subsection{Potensi CAR-T Cell Termodifikasi CRISPR/Cas9}

Sistem imun memainkan peran penting dalam perkembangan kanker. Dalam keadaan normal, sistem kekebalan tubuh dapat mengenali, mengontrol, dan bahkan menghilangkan tumor. Sel CD8+ adalah sel imun utama yang bertanggung jawab untuk membunuh sel tumor. Salah satu mekanisme yang digunakan oleh tumor adalah meningkatkan regulasi dari Programmed Death-Ligand 1 (PD-L1), yang telah diidentifikasi sebagai indikator prognosis buruk pada beberapa jenis tumor. ${ }^{[64]}$

Sel CD8+ mengekspresikan programmed cell death protein 1 (PD1) pada permukaannya, sedangkan PDL1 diekspresikan oleh sebagian besar jenis sel, termasuk juga sel tumor. Ikatan PD-1 dengan PD-L1 memainkan peran penting dalam sistem kekebalan untuk menjaga toleransi imun dan respons imun fisiologis yang seimbang. sel tumor dapat memanfaatkan jalur PD-1/PD-L1 untuk melemahkan aktivitas sel CD8+. PD-1 ketika berikatan dengan pada ligannya PD-L1, menghasilkan inhibitory signals untuk menekan aktivitas Sel CD8+. ${ }^{[64]}$ Begitu pula dengan CAR-T cell yang menunjukkan penurunan fungsi untuk terapi tumor sebagian karena efek supresif diakibatkan oleh ekspresi PD-1 mereka sendiri. Penurunan fungsi ini termasuk penurunan kemampuan sitotoksik dan sekresi sitokin CAR-T Cell.[63] Untungnya, downregulasi yang diinduksi oleh tumor untuk fungsi $C A R-T$ Cell dapat dituntaskan dengan menggunakan blokade PD-1 yang dapat mempertahankan aktivasi CAR-T Cell sebagai terapi tumor. ${ }^{[65]}$ Oleh karena itu, kombinasi CAR-T Cell dan PD-1 inhibitor dapat meningkatkan kontrol tumor dan kelangsungan hidup. ${ }^{[64]}$ Salah satu metode yang digunakan untuk blokade PD-1 adalah dengan metode lentivirus CRISPR/Cas9.

Gambar 3 menjelaskan protokol skematik produksi lentivirus CRISPR/Cas9. Untuk produksi lentivirus CRISPR/Cas9, non-targeting guide $R N A$ sequence dan tiga $P D-1$ guide RNA sequences dirancang menggunakan program online http://crispr.mit.edu. $P D-1$ guide RNA sequence PD-1sg-1: aggcgccctggccagtcgtc, PD-1sg-2: cgtctgggcggtgctacaac, PD-1sg-3: ctacaactgggctggcggcc dan nontargeting control RNA sequence: atcgtttccgctcg. Lentivirus diproduksi menggunakan co- transfecting sel 293T dengan kemasan vektor ps-PAX2, envelope vektor $\mathrm{pCL}$ - VSVG dan masing-masing vektor LentiCrispr V2. 24 jam setelah transfeksi, media kultur diubah menjadi RPMI disuplementasi dengan 10\% FBS. Lentivirus dalam supernatant dikumpulkan 72 jam setelah transfeksi dan disaring melalui $0,45 \mu \mathrm{m}$ syringe filter. ${ }^{[64]}$ 
Protocol for CRISPR editing and lentiviral transduction
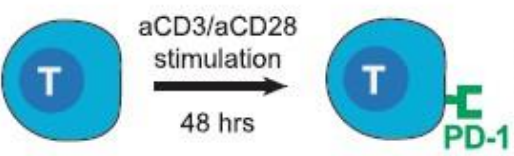

(1) PD-1 editing

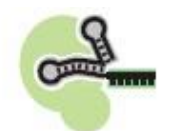

Nucleofection of Cas9 RNP
$48 \mathrm{hrs}$ Gambar 3. Protokol skematik untuk modifikasi kombinasi gen CRISPR dan transduksi
lentiviral pada sel CD8+ manusia.[24]

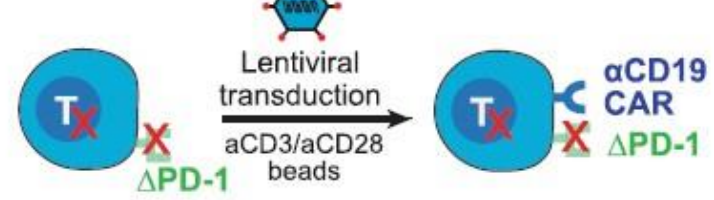

$\begin{array}{ccc}\text { Hasil dari } & \text { CAR-T } & \text { Cell } \\ \text { CRISPR/Cas9 untuk }\end{array}$ termodifikasi CRISPR/Cas9 untuk
blokade PD-1 menunjukkan hasil yang baik pada uji in vitro maupun uji in vivo. CAR-T Cell termodifikasi CRISPR/Cas9 menunjukkan peningkatan degranulasi
CAR-T Cell pada uji in vitro dibandingkan dengan CAR-T Cell tanpa modifikasi (Lihat gambar 4). Pada uji in vivo, CAR-T Cell termodifikasi CRISPR/Cas9 meningkatkan clearance tumor dengan signifikan (Lihat gambar 5). ${ }^{[24]}$

\section{degranulation (CD8+)}

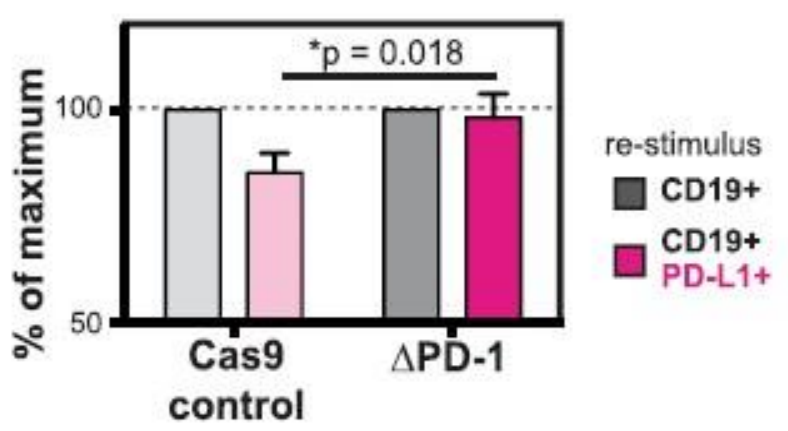

Gambar 4. Blokade PD-1 pada CD8+ anti-CD19 CAR-T Cell ( $\triangle \mathrm{PD}-1)$ menunjukkan degranulasi yang lebih besar dibandingkan dengan kontrol CD8+CAR-T Cell.[24]

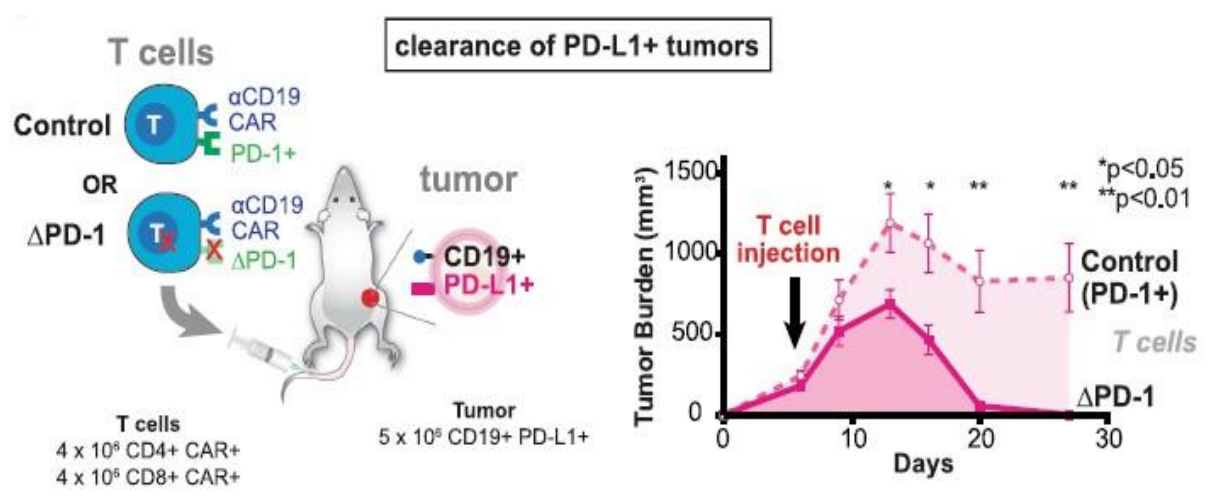

Gambar 5. CAR-T Cell termodifikasi CRISPR/Cas9-mediated anti PD-1 meningkatkan fungsi sel anti-CD19 CAR-T Cell dan meningkatkan clearance tumor in vivo. ${ }^{[24]}$ 


\section{SIMPULAN}

Banyak

peneliti telah melakukan uji coba pada metode dan mekanisme terapi kanker prostat. Salah satu metode yang paling mutakhir adalah terapi CAR-T Cell dengan target PSMA termodifikasi CRISPR/Cas9 yang dapat secara langsung menargetkan sel kanker prostat. Disrupsi PD-1 pada $C A R-T$ Cell menggunakan metode CRISPR/Cas9 menunjukkan efek yang signifikan terhadap peningkatan degranulasi CAR-T Cell dan clearance tumor. Oleh karena itu, metode terapi ini berpotensi sebagai inovasi terapi yang efektif, efisien, dan dapat menjadi modalitas terapi pada kanker prostat.

\section{SARAN}

Untuk penelitian selanjutnya, diperlukan penelitian mengenai jumlah dosis CAR-T Cell termodifikasi CRISPR/Cas9-mediated anti PD-1 yang harus diinjeksi, efek sampingnya, efektivitas pada manusia, serta penggunaan terapi ini pada penyakit lainnya.

\section{DAFTAR PUSTAKA}

1. Kumar V, Abbas AK, Aster JC. Robbins Basic Pathology. Ninth Edit. Philadelphia, Pennsylvania: Elsevier; 1390. $668 \mathrm{p}$.

2. Mottet N, Bellmunt J, Briers E, Bergh RCN van den, Bolla $M$, Casteren NJ van, et al. Guidelines on Prostate Cancer [Internet]. European Association of Urology. 2015. 31-45 p. Available from: http://www.uroweb.org/fileadmin/tx _eauguidelines/2005/Pocket/Prost ate_Cancer.pdf

3. Castillejos-molina RA, Gabilondonavarro FB. Prostate Cancer. Salud Publica Mex. 2016;58(2):279-84.

4. Baade PD, Youlden DR, Cramb SM, Dunn J, Gardiner RA. Epidemiology of prostate cancer in the Asia-Pacific region. Prostate Int [Internet]. 2013;1(2):47-58. Available from: http://dx.doi.org/10.12954/PI.1201 4

5. Crawford ED, Petrylak D, Sartor O.Navigating the evolving therapeutic landscape in advanced prostate cancer. Urol Oncol Semin
Orig Investig [Internet]. 2017;35(01):1-10. Available from: http://dx.doi.org/10.1016/j.urolonc. 2017.01.020

6. Lawrenti H. Perkembangan Terapi Kanker Prostat. CKD. 2019;46(8):521-8.

7. Ferlay J, Colombet $\mathrm{M}$, Soerjomataram I, Mathers C, Parkin DM, Piñeros $M$, et al. Estimating the global cancer incidence and mortality in 2018: GLOBOCAN sources and methods. Int J Cancer [Internet]. 2019;144(8):1941-53. Available from:

https://www.ncbi.nlm.nih.gov/pubm ed/30350310

8. The Global Cancer Observatory G. Prostate 2018. World Health Organization. 2019.

9. Rawla P. Descriptive Epidemiology of Prostate Cancer. World J Oncol. 2019;10(2):63-89.

10. International Agency for Research on Cancer. Cancer Tomorrow. World Health Organization (WHO). 2019.

11. Kementerian Kesehatan Republik Indonesia. Panduan Penatalaksanaan Kanker Prostat. Komite Penanggulangan Kanker Nasional. 2015. 47 p.

12. Kementerian Kesehatan Republik Indonesia. Keputusan Menteri Kesehatan RI Nomor Hk.01.07/Menkes/291/2018

Tentang Pedoman Nasional Pelayanan Kedokteran Tata Laksana Kanker Prostat [Internet]. Komite Penanggulangan Kanker Nasional. Jakarta; 2018. 9-42 p. Available from: http://kanker.kemkes.go.id/guidelin es/PNPKProstat.pdf

13. Krstev S, Knutsson A. Occupational Risk Factors for Prostate Cancer: A Meta-analysis. J Cancer Prev. 2019;24(2):91-111.

doi:10.15430/JCP.2019.24.2.91

14. Silva JF, Mattos IE, Luz LL, Carmo $\mathrm{CN}$, Aydos RD. Exposure to pesticides and prostate cancer: systematic review of the literature. Rev Environ Health. 2016;31(3):311-327. doi:10.1515/reveh-2016-0001

15. Kachuri L, Harris MA, MacLeod JS, Tjepkema M, Peters PA, Demers 
PA. Cancer risks in a populationbased study of 70,570 agricultural workers: results from the Canadian census health and Environment cohort (CanCHEC). BMC Cancer. 2017;17(1):343. Published 2017 May 19. doi:10.1186/s12885-0173346- $x$

16. Miller KD, Nogueira $L$, Mariotto $A B$, Rowland $\mathrm{JH}$, Yabroff KR, Alfano $\mathrm{CM}$, et al. Cancer treatment and survivorship statistics, 2019. CA: A Cancer Journal for Clinicians. 2019Nov;69(5):363-85.

17. Teo MY, Rathkopf DE, Kantoff P. Treatment of Advanced Prostate Cancer. Annu Rev Med. 2019;70:479-499.

doi:10.1146/annurev-med-051517011947

18. Perdana NR, Mochtar CA, Umbas HR, Hamid ARAH. The Risk Factors of Prostate Cancer and Its Prevention. Acta medica Indonesiana. $2016 \quad \mathrm{Jul}$ 1;48(3):228-238.

19. Gamat M, McNeel DG. Androgen deprivation and immunotherapy for the treatment of prostate cancer. Endocr Relat Cancer. 2017;24(12):T297-T310.

doi:10.1530/ERC-17-0145

20. Bilusic M, Madan RA, Gulley JL. Immunotherapy of Prostate Cancer: Facts and Hopes. Clin Cancer Res. 2017;23(22):67646770. doi:10.1158/10780432.CCR-17-001921.

Sountoulides $P$, Rountos $T$. Adverse effects of androgen deprivation therapy for prostate cancer: prevention and management. ISRN Urol. 2013;2013:240108. Published 2013 Jul 25. doi:10.1155/2013/240108

22. Yu H, Pan J, Guo Z, Yang C, Mao L. CART cell therapy for prostate cancer: status and promise. Onco Targets Ther. 2019;12:391-395. Published 2019 Jan 3. doi:10.2147/OTT.S185556

23. Sha HH, Wang DD, Yan DL, et al. Chimaeric antigen receptor T-cell therapy for tumour immunotherapy. Biosci Rep. 2017;37(1):BSR20160332. Published 2017 Jan doi:10.1042/BSR20160332
24. Rupp LJ, Schumann K, Roybal KT, et al. CRISPR/Cas9-mediated PD1 disruption enhances anti-tumor efficacy of human chimeric antigen receptor $\mathrm{T}$ cells. Sci Rep. 2017;7(1):737. Published 2017 Apr 7. doi:10.1038/s41598-01700462-8

25. Chen H, Choi J, Bailey S. Cut site selection by the two nuclease domains of the Cas9 RNA-guided endonuclease. $J$ Biol Chem. 2014;289(19):13284-13294.

doi:10.1074/jbc.M113.539726

26. Fay AP, Antonarakis ES. Blocking the PD-1/PD-L1 axis in advanced prostate cancer: are we moving in the right direction?. Ann Transl Med. 2019;7(Suppl 1):S7. doi:10.21037/atm.2019.01.37

27. Wallis CJD, Nam RK. Prostate Cancer Genetics: A Review. Ejifcc Int Fed Clin Chem Lab Med [Internet]. 2015;26(2):79-91. Available from: http://www.ncbi.nlm.nih.gov/pubm ed/27683484\%0Ahttp://www.pubm edcentral.nih.gov/articlerender.fcgi ?a rtid=PMC4975354.

28. Ricke EA, Williams $K$, Lee $Y F$, Couto S, Wang Y, Hayward SW, et al. Androgen Hormone Action in Prostatic Carcinogenesis: Stromal Androgen Receptors Mediate Prostate Cancer Progression, Malignant Transformation and Metastasis. Carcinogenesis. 2012;33(7):1391-8.

29. Simoes GF, Sakuramoto $P$, Santos CB dos, Furlan NKC, Augusto TM. An Overview on Prostate Pathophysiology: New Insights into Prostate Cancer Clinical Diagnosis. In: PathophysiologyAltered Physiological States. Brazil: IntechOpen; 2018. p. 183202.

30. Ragin C, Davis-Reyes B, Tadesse $\mathrm{H}$, Daniels D, Bunker $\mathrm{CH}$, Jackson $M$, et al. Farming, Reported Pesticide Use, and Prostate Cancer. Am J Mens Health. 2013;7(2):102-9.

31. Stopsack KH, Mucci LA, Antonarakis ES, Nelson PS, Kantoff PW. TMPRSS2 and COVID-19: Serendipity or opportunity for intervention? 
Cancer Discov Am Assoc Cancer Res. 2020;10(1):1-4.

32. Baena E, Shao Z, Linn DE, Glass $\mathrm{K}$, Hamblen MJ, Fujiwara Y, et al. ETV1 Directs Androgen Metabolism and Confers Aggressive Prostate Cancer in Targeted Mice and Patients. Genes Dev. 2013;27(6):683-98.

33. Linn DE, Bronson RT, Li Z. Genetic Interaction Between Tmprss2-ERG Gene Fusion and Nkx3.1-loss does not Enhance Prostate Tumorigenesis in Mouse Models. PLoS One. 2015;10(3):1-12.

34. St. John J, Powell K, Katie ConleyLaComb M, Chinni SR. TMPRSS2ERG Fusion Gene Expression in Prostate Tumor Cells and Its Clinical and Biological Significance in Prostate Cancer Progression. J Cancer Sci Ther. 2012;4(4):94101.

35. Liu CY, Yu T, Huang Y, Cui L, Hong W. ETS (E26 transformationspecific) Up-regulation of the Transcriptional co-Activator TAZ Promotes Cell Migration and Metastasis in Prostate Cancer. J Biol Chem. 2017;292(22):9420-30.

36. Mottet N, Bergh van den, Briers E, Cornford P, Grummet J, Santis, et al. EAU - EANM - ESTRO - ESUR - SIOG Guidelines on Prostate Cancer 2019 [Internet]. European Association of Urology Guidelines 2019. European Association of Urology; 2019. 1-161 p. Available from:

https://uroweb.org/guideline/prosta t e-cancer

37. Chen CY, Chen J, He L, Stiles BL. PTEN: Tumor Suppressor and Metabolic Regulator. Front Endocrinol (Lausanne). 2018;9(338):1-12.

38. Rubin MA, Maher CA, Chinnaiyan AM. Common Gene Rearrangements in Prostate Cancer. J Clin Oncol. 2011;29(27):3659-68.

39. Ness N, Andersen S, Khanehkenari MR, Nordbakken C V., Valkov A, Paulsen EE, et al. The Prognostic Role of Immune Checkpoint Markers Programmed Cell Death Protein 1 (PD-1) and Programmed Death Ligand 1 (PDL1) in a Large, Multicenter Prostate
Cancer Cohort. Oncotarget. 2017;8(16):26789-801.

40. Tumeh PC, Harview CL, Yearley $\mathrm{JH}$, Shintaku IP, Emma J, Taylor M, et al. PD-1 Blockade Induces Responses by Inhibiting Adaptive Immune Resistance. Nature. 2015;515(7528):568-71.

41. Fay AP, Antonarakis ES. Blocking the PD-1/PD-L1 Axis in Advanced Prostate Cancer. Ann Transl Med. 2019;7:1-4.

42. Gevensleben H, Dietrich D, Golletz C, Steiner S, Jung M, Thiesler T, et al. The Immune Checkpoint Regulator PD-L1 is Highly Expressed in Aggressive Primary Prostate Cancer. Clin Cancer Res. 2016;22(8):1969-77.

43. Sharma $M$, Yang $Z$, Miyamoto $H$, Lucarelli G. Immunohistochemistry of Immune Checkpoint Markers PD-1 and PD-L1 in Prostate Cancer. Med (United States). 2019;98(38):1-6.

44. Bardhan $\mathrm{K}$, Anagnostou $\mathrm{T}$, Boussiotis VA. The PD1: PD-L1/2 Pathway from Discovery to Clinical Implementation. Front Immunol. 2016;7(550):1-17.

45. Yeku O, Slovin SF. Immune Therapy for Prostate Cancer. Cancer J. 2016;22(5):334-341. doi:10.1097/PPO.0000000000000 223

46. Sadelain M, Brentjens R, Rivière I. The basic principles of chimeric antigen receptor design. Cancer Discov. 2013;3(4):388-398. doi:10.1158/2159-8290.CD-120548

47. Benmebarek MR, Karches $\mathrm{CH}$, Cadilha BL, Lesch S, Endres S, Kobold S. Killing Mechanisms of Chimeric Antigen Receptor (CAR) T Cells. Int $J$ Mol Sci. 2019;20(6):1283. Published 2019 Mar 14. doi:10.3390/ijms20061283

48. Magee MS, Snook AE. Challenges to chimeric antigen receptor (CAR)$\mathrm{T}$ cell therapy for cancer. Discov Med. 2014;18(100):265-271.

49. Yu S, Li A, Liu Q, et al. Chimeric antigen receptor $T$ cells: a novel therapy for solid tumors. J Hematol Oncol. 2017;10(1):78. Published 2017 Mar 29. doi:10.1186/s13045017-0444-9 
50. Westdorp H, Sköld AE, Snijer BA, et al. Immunotherapy for prostate cancer: lessons from responses to tumor-associated antigens. Front Immunol. 2014;5:191. Published $2014 \quad$ May 6. doi:10.3389/fimmu.2014.00191

51. Junghans RP, Ma Q, Rathore R, et al. Phase I Trial of Anti-PSMA Designer CAR-T Cells in Prostate Cancer: Possible Role for Interacting Interleukin 2-T Cell Pharmacodynamics as a Determinant of Clinical Response. Prostate. 2016;76(14):1257-1270. doi:10.1002/pros.23214

52. Slovin SF, Wang $X$, Hullings $M$, Arauz G, Bartido S, Lewis JS, Schöder H, Zanzonico P, Scher HI, Sadelain M, et al. Chimeric antigen receptor (CAR+) modified $T$ cells targeting prostate-specific membrane antigen (PSMA) in patients (pts) with castrate metastatic prostate cancer (CMPC). J. Clin. Oncol. 2013;31. doi:

10.1200/jco.2013.31.6_suppl.72

53. Diao W, Cai H, Chen L, Jin X, Liao $X$, Jia Z. Recent Advances in Prostate-Specific Membrane Antigen-Based

Radiopharmaceuticals. Curr Top Med Chem. 2019;19(1):33-56. doi:10.2174/15680266196661902 01100739

54. Ullah K, Addai Peprah F, Yu F, Shi $\mathrm{H}$. The application of prostate specific membrane antigen in CART-cell therapy for treatment of prostate carcinoma (Review). Oncol Rep. 2018;40(6):3136-3143. doi:10.3892/or.2018.6758

55. Schepisi, G., Cursano, M.C., Casadei, C. et al. CAR-T cell therapy: a potential new strategy against prostate cancer. $j$. immunotherapy cancer 7, 258 (2019).

https://doi.org/10.1186/s40425019-0741-7

56. Hofman MS, Hicks RJ, Maurer T, Eiber M. Prostate-specific Membrane Antigen PET: Clinical Utility in Prostate Cancer, Normal Patterns, Pearls, and Pitfalls. Radiographics. 2018;38(1):200217. doi:10.1148/rg.2018170108
57. Textor A, Listopad JJ, Wuhrmann LL, Perez C, Kruschinski A, Chmielewski M, et al. Efficacy of CAR T-cell therapy in large tumors relies upon stromal targeting by IFNgamma. Cancer Res. 2014;74(23):6796-805

58. Zhang Q, Helfand BT, Carneiro BA, et al. Efficacy Against Human Prostate Cancer by Prostatespecific Membrane Antigenspecific, Transforming Growth Factor- $\beta$ Insensitive Genetically Targeted CD8 ${ }^{+}$T-cells Derived from Patients with Metastatic Castrate- resistant Disease. Eur Urol. 2018;73(5):648-652. doi:10.1016/j.eururo.2017.12.008

59. Cong L, Zhang F. Genome engineering using CRISPR-Cas9 system. Methods Mol Biol. 2015;1239:197-217.

doi:10.1007/978-1-4939-18621_10

60. Rodríguez-Rodríguez DR, Ramírez-Solís R, Garza-Elizondo MA, Garza-Rodríguez ML, BarreraSaldaña HA. Genome editing: A perspective on the application of CRISPR/Cas9 to study human diseases (Review). Int $\mathrm{J} \mathrm{Mol} \mathrm{Med.}$ 2019;43(4):1559-1574.

doi:10.3892/ijmm.2019.4112

61. Redman M, King A, Watson C, King D. What is CRISPR/Cas9?. Arch Dis Child Educ Pract Ed. 2016;101(4):213-215.

doi:10.1136/archdischild-2016310459

62. Ryu SM, Hur JW, Kim K. Evolution of CRISPR towards accurate and efficient mammal genome engineering. $B M B$ Rep. 2019;52(8):475-481. doi:10.5483/BMBRep.2019.52.8.1 49

63. Hu W, Zi Z, Jin $Y$, et al. CRISPR/Cas9-mediated PD-1 disruption enhances human mesothelin-targeted CAR T cell effector functions. Cancer Immunol Immunother. 2019;68(3):365-377. doi:10.1007/s00262-018-2281-2

64. Zhao Z, Shi L, Zhang W, et al. CRISPR knock out of programmed cell death protein 1 enhances antitumor activity of cytotoxic $T$ lymphocytes. Oncotarget. 2017;9(4):5208-5215. Published 
2017

Dec 27.

doi:10.18632/oncotarget.23730

65. Guo $X$, Jiang $H$, Shi $B$, et al.

Disruption of PD-1 Enhanced the

Anti-tumor Activity of Chimeric

Antigen Receptor T Cells Against

Hepatocellular Carcinoma. Front

Pharmacol. 2018;9:1118.

Published 2018 Oct 1.

doi:10.3389/fphar.2018.01118 